\title{
ISLAM NUSANTARA SEBAGAI MANIFESTASI NAHDLATUL ULAMA (NU) DALAM MEWUJUDKAN PERDAMAIAN
}

\section{Dra.Tuti Munfaridah, MSI}

IAIIG Cilacap

tutimnfarida17@gmail.com

\begin{abstract}
Abstrak
The phenomenon is seen in today's society is the impression that; "Islam is a terrorist, bomb, loud, kill, covered and other labels that is contrary to the teachings of Islam itself be rahmatan li al-'alamaeen." Even in the Western world was antipathy to Islam so as to "hear" the word Islam alone horror and antipathy even hate.

In such a condition that the term "Islam Nusantara" among leaders Nahdtlatul Ulama Ulama (NU). But the reality in society the term Islam Nusantara still very strange, even among radical Islam mengangggap "Islam Nusantara" is Islam perverted access all religions in Indonesia, or Islam "mix" of various religions in Indonesia, instead of pure Islam as taught by Prophet Muhammad SAW.

From some of the conditions that exist in society on the understanding of "terrorists and Islam Nusantara" raises anxiety on academic researchers to seek answers on "Terrorism, Islam Nusantara and rahmatan lil'alamin."

Nahdtlatul Ulama (NU) is the largest organization in Indonesia as a representation of Muslims. An understanding of terrorism, Islam and Islam Nusantara rahmatan lil 'Alamin will be extracted from the Branch Executive Nahdtlatul Ulama (PCNU) Cilacap. Researchers assume that; Nahdtlatul Ulama (NU) is a representation of Islam Nusantara that Branch Executive Nahdtlatul Ulama (PCNU) Cilacap also have an important role in preaching / called on Muslims to implement the teachings of Islam Nusantara for the realization rahmatan lil'alamin.

This study is a qualitative research field, thus Researchers will use qualitative research methods with random sampling theory Milles accordance with the triangulation of data. While the idea is inductive qualitative groove.

This Researchers can to know about Islam Nusantara is very nice, humbly, savety and
\end{abstract}


so good to implemantion and aplication in the religious life and social relation in this country, many others and world. Islam Nusantara is true religion, that Islam from propet Muhammad SAW, not new Islam. So we must be recieved its.

Key word: Islam Nusantara, Nahdlatul Ulama, Perdamaian.

\section{A. Pendahuluan}

Istilah Islam Nusantara adalah istilah baru, baru lahir, sehingga masih sangat hangat dan ramai menjadi perbincangan di kalangan Ulama dan masyarakat. Ibarat bayi baru lahir, banyak yang ingin tahu dan penasaran. Banyak pertanyaan yang perlu dijawab dari rasa penasaran dan keingintahuan yang bergejolak di masyarakat. Siapa yang melahirkan, bagaimana proses lahirnya, seperti apa bentuknya, apakah sesuai dengan bentuk asli nasab/ayahnya atau berbeda tapi mirip, dan lain-lain.

Semua pertanyaan dan rasa penasaran ini perlu dijawab dengan tepat sesuai kenyataannya, bukan jawaban semu atau palsu dan mengarang atau meraba-raba. Melalui penelitian ini akan diapaparkan Islam Nusantara secara jelas secara aktual baik dalam bentuk teoritik maupun praktik empirik dari pendapat Ulama dan sejarah kelahirannya.

Untuk menghilangkan rasa penasaran dan pemahaman yang keliru tentang Islam Nusantara serta mendapat jawaban yang tepat, Penulis melakukan Pnelitian tentang Islam Nusantara. Penulis mencari data-data penelitian melalui observasi, studi dokumentasi dan melakukan wawancara dengan para Ulama dan tokoh masyarakat di Kabupaten Cilacap. Berikut adalah tulisan hasil penelitian yang telah diringkas menjadi naskah jurnal ilmiah.

\section{B. Pembahasan}

\section{Konsep Dasar Islam Nusantara}

Dilihat dari sejarah munculnya istilah, Islam Nusantara sebenarnya merupakan perwujudan nilai-nilai Islam yang telah berakulturasi dengan budaya lokal, yaitu budaya Nusantara/ Indonesia. Hal ini dapat dilihat dari ciri penerapan Islam Nusantara itu sendiri. Hal ini bisa terjadi karena beberapa sebab, yaitu pertama relasi yang kuat antara Islam dan budaya lokal. Kedua,keberpijkan agama terhadap tanah air (Nusantara). Ketiga, dengan kecintaan pada tradisi dan tanah air, terbukti Islam Nusantara tidak pernah memberontah pada pemerintah yang syah. Karena dilandasi ajaran ahlusunnah wal jamaah yang memiliki karakter tasamuh (toleransi/ fleksibel), tawasuth (moderat), tawazun (seimbang) dan itidal (menjaga keadilan).

Karakteristik tersebut menjadi roh Islam Nusantara sehingga mewujudkan wajah yang ramah, damai, santun, dan menyejukkan. Karena ajarannya dapat diselaraskan dengan konteks atau kondisi sosial masyarakat sehingga terjadi akulturasi dengan budaya dan kondisi sosial politik masyarakat setempat.

Islam Nusantara adalah Islam yang khas ala Indonesia, gabungan nilai Islam teologi dengan nilai-nilai tradisi lokal, budaya dan adat-istiadat di Tanah air. Karakter Islam Nusantara menunjukkan adanya kearifan lokal di Nusantara yang tidak melanggar ajaran Islam, tapi justru 
mensinergikan dengan adat-istiadat yang ada di wilayah Indonesia. Islam Nusantara adalah Islam yang ramah, terbuka, inklusif dan mampu memberi solusi terhadap masalah-masalah besar Bangsa dan negara. Islam yang dinamis, bersahabat dengan lingkungan kultur, sub kultur, dan agama yang beragam. ${ }^{1}$

Pemahaman, pengalaman dan metode dakwah Ulama Nusantara, sejauh ini telah memberi kesan yang baik, yaitu Islam yang tampil dengan wajah sumringah, tidak pongah, toleran tapi tidak plin-plan, indah dan damai.

Ada beberapa pendapat para tokoh negara dan agama yang menggambarkan konsep Islam Nusantara, seperti yang dikemukakan oleh KH Said AqilnSirad Ketua PBNU "Islam Nusantara sebagai bentuk penegasan Islam yang memberi kesejahteraan dan kedamaian bagi seluruh rakyat Indonesia.” Prof.Dr. Azymardi Azra-tokoh pemikiran Islam mengatakan ; “....Islam Nusantara dibutuhkan oleh masyarakat dunia saat ini, karena ciri khasnya mengedepankan”jalan tengah.”

Bapak Jokowi -Presiden RI mengatakan; "Islam Nusantara adalah Islam yang ramah, tidak radikal, inklusif dan toleran.” Sedangkan Rois Syuriah PBNU, Bapak KH Masdar Farid Mas'udi mengatakan bahwa, Islam Nusantara sebagai Islam global, Islam yang penuh toleransi, kepada yang berbeda keyakinan atau paham. Bukan karena Indonesia menjadi tempat turunnya wahyu, tapi kita bisa banggakan Islam Indonesia yang penuh toleransi bukan retorika.

Bahkan tokoh duniapun menyambut positif terhadap Islam Nusantara. Misalnya, Dr. James B Hoesterey - pakar Islam Universitas Emory di Atlanta, Georgia, AS berpendapat bahwa, Islam Nusantara sebagai gagasan yang layak dicontoh oleh dunia internasional. Juga Dr. Clara FormichiPakarSejarah Islam Universitas Cornell di Ithaca, New York mengatakan"Gagasan Islam Nusantara sangat erat dengan sejarah dan budaya Indonesia. Saya tidak tahu bisa diterapkan di negara lain atau tidak, tetapi yang jelas bisa menjadi contoh untuk mengerti mengapa seseorang memeluk Islam." ${ }^{3}$

"Islam Nusantara adalah gabungan nilai Islam teologis dengan nilai-nilai tradisi lokal, budaya, dan adat istiadat di Tanah Air. Ini bukan barang baru di Indonesia. Sebagai organisasi masyarakat Islam, Nahdlatul Ulama menjalankan konsep Islam Nusantara yang menunjukkan kearifan lokal Indonesia," kata Ketua Umum PBNU KH Said Aqil Siroj. ${ }^{4}$

Sedangkan dari Penelitian yang dilakukan oleh Penulis, menurut para Ulama di Kabupaten Cilacap yang merupakan Pengurus Cabang Nahdlatul Ulama (PCNU) Kabupaten Cilacap, dapat disimpulkan bahwa; Islam Nusantara adalah, Islam yang mengedepankan rahmat/ kasih sayang, yang menyejukkan, melindungi, moderat, menerima budaya lokal yang tidak bertentangan dengan ajaran Islam, yang mementingkan dialog atau menyelaraskan nash syar'i dan realitas, bukan hanya ritual, melainkan tetap sesuai dengan basis pengetahuan dan khazanah budaya sehingga terwujudnya harmoni antara agama, budaya dan bangsa itu sendiri yang merupakan manifestasi ajaran Ablusunnab wal jamaab (Aswaja) yang diajarkan dan

1 Ahmad Sahal, 2015, Munawir Aziz (editor), Islam Nusantara dari Ushul Fiqh hingga konsep Historis, PT Mizan Pustaka, Bandung, hlm. 239-240

2 AULA, 2015, PT AULA Media Nahdlatul Ulama, Surabaya, hlm.18

3 AULA, 2015, PT AULA Media Nahdlatul Ulama, Surabaya, hlm.19

4 Situs resmi PCNU Kabupaten Cilacap online 
diamalkan oleh Nahdlatul Ulama (NU) baik berasal dari dalam organisasi Nahdlatul Ulama (NU) itu sendiri maupun dari organisasi lain yang sepaham dengan Nahdlatul Ulama (NU). Karena di luar Nahdlatul Ulama (NU) banyak yang mengklaim sebagai Islam Ahlusunnah wal jamaah tetapi dalam pengamalan ajarannya tidak sama dengan NU, padahal Islam Nusantara adalah pemahaman Islam gagasan NU.

\section{Perbedaan Islam Nusantara dan Pribumisasi Islam}

Sebenarnya jauh sebelum Istilah Islam Nusantara lahir telah ada gagasan yang senada yaitu gagasan tentang munculnya ide "Fiqh Indonesia." Pada tahun 1961 Prof. Dr Hasbi Assidqi pada acara Dies Natalis pertama IAIN Sunan Kalijaga menyampaikan gagasan "Fiqh Indonesia." Yang dimaksud adalah fiqh yang diterapkan di Indonesia yang sesuai dengan kepribadian masyarakat Indonesia.

Najib Burhani seorang tokoh intelektual muda Muhammadiyah berusaha memberi pemahaman bahwa Islam Nusantara sama dengan Islam berkemajuan dalam organisasi Muhammadiyah. Beliau berkata; "langgamnya Nusantara tapi isinya Islam, bajunya Indonesia tapi badannya Islam." 5 Tapi pemahaman Najib Burhani tidak bisa diterima oleh NU karena Islam Nusantara menekankan pembaharuan pemahaman Islam karena perubahan konteks geografis dari Arab ke Nusantara. Sedangkan paham Islam berkemajuan dalam Muhammadiyah menyerukan pembaharuan Islam karena perubahan zaman memerlukan pembaharuan/tajdid. Titik temu kontekstualisasi Islam versi Muhammadiyah dan NU tercermin dalam pemikiran Prof.Dr.Amin Abdullah dan KH Sahal Mahfudz tentang hukum Islam. Bagi Prof.Dr.Amin Abdullah perubahan zaman klasik -skolastik ke era modern menuntut digalakkannya ijtihad kontemporer, ijtihad yang segar (fresh ijtihad). Konsep fikih sosial dan kalam sosial Prof.Dr. Amin Abdullah menujukkan adanya kemiripan dengan Fiqih sosial KH Sahal Mahfudz.

Di kalangan nahdliyin, tema Islam Nusantara menandai perkembangan terkini dari pemikiran NU. Pada tahun 1980 KH Abdurrahman Wahid (Gus Dur), mengenalkan ide "Pribumisasi Islam." Intinya: Islam sebagai agama universal harus dibumikan ke dalam budaya lokal. Ini dilakukan agar Muslim Indonesia bisa beragama sesuai dengan budaya Indonesia.

"Kita ambil nilai Islam, kita saring budaya Arab-nya", demikian Gus Dur menandaskan. Islam Indonesia. Dari sini lahirlah istilah Islam Indonesia. Maksudnya tentu saja jelas: Islam yang berbudaya Indonesia. Dalam praktik diskursifnya, Islam Indonesia ditempatkan dalam konteks keindonesiaan modern, yang bernegara-bangsa, berpancasila, dan demokratis. Ini digunakan oleh nahdliyin sebagai norma dasar yang memayungi geliat pemikiran dan gerakan sosialnya. Ketika terjadi "bom intelektual” NU pada akhir 1990-an, gagasan Islam Indonesia diradikalkan dalam rangka sekularisasi, liberalisasi, dan pluralisme.

Hal itu melahirkan reaksi berupa post-tradisionalisme Islam (postra). Gagasan ini sederhana, menandai perbedaan titik pijak antara Gus Dur dan Nurcholish Madjid (Cak Nur). Bagi postra, pijakan Gus Dur ialah tradisi. Sementara Cak Nur, modernitas Eropa. Maka, gerakan pemikiran

5 Ahmad Sahal, 2015, Munawir Aziz (editor), Islam Nusantara dari Ushul Figh hingga konsep Historis, PT Mizan Pustaka, Bandung, hlm.28-29 
NU mengalami arus balik, dari liberalisme menuju tradisi.

Pertarungan pemikiran di atas tentu terhenti pada level paradigmatis. Sebab, baik kubu liberal maupun postra tidak benar merumuskan epistemologi dan metodologi. Semuanya hanya "dentuman besar" layaknya balon, yang ketika meledak, ia hancur dan kosong.

Dalam kondisi inilah Islam Nusantara adalah menjadi perkembangan terkini geliat pemikiran NU. Ia lebih baik karena beberapa alasan. Pertama, menempatkan pribumisasi Islam sebagai metodologi. Jika pada masa Gus Dur pribumisasi murni dikonsumsi, pada era kini, ia menjadi metodologi bagi perumusan Islam Nusantara.

Hal ini memungkinkan karena Gus Dur menekankan tentang hal tersebut, di mana pribumisasi Islam merupakan proses perwujudan nilai-nilai Islam melalui (bentuk) budaya lokal. Ini dilakukan baik melalui kaidah fikih (al-'adah al-muhakkamah: adat bisa menjadi hukum) maupun pengembangan aplikasi nash (teks suci). Dengan cara ini, perdebatan pemikiran lebih bersifat akademik, terlihat dari pendirian program studi Islam Nusantara di lingkungan perguruan tinggi NU.

Kedua, mempraksiskan pemikiran ke ranah ketekunan riset. Ini dibutuhkan karena Islam Nusantara merupakan kajian historis, antropologis, dan arkeologis. Dalam wilayah ini, tugas NU masih luas, terutama merumuskan "status ontologis" Islam Nusantara yang berbeda dengan Islam lain. Sejauh ini kemajuan telah terjadi dengan ditelitinya "corak budaya" dan "mekanisme kultural" Islam Nusantara, terutama era Wali Songo.

Ketiga, memperjelas akar tradisi, dari pesantren (di dalamnya terdapat tradisi Sunni) kepada Islam Nusantara. Hal ini penting mengingat selama ini, NU hanya dipijakkan pada pesantren. Sementara pesantren adalah hasil darigelombangketigaislamisasiNusantarasetelahfasetasawufdan syariatisasi. Keberpijakan hanya pada pesantren, mengalpakan "lambaran kultural Islam" tersebut.

\section{Sepuluh Prinsip Dasar Islam Nusantara ${ }^{6}$}

Dari Artikel "Sepuluh Prinsip Dasar Islam Nusantara" yang ditulis oleh Prof. Dr. M. Isom Yusqi, Direktur Pascasarjana STAINU Jakarta; Faris Khoirul Anam, pengurus Aswaja NU Center Jatim, adalah sebagai berikut: Meskipun uraian mabadi asyrah ini pada mulanya berkaitan dengan ilmu syariah, namun informasi mengenai suatu istilah, disiplin ilmu atau kajian/diskursus yang baru tidak ada salahnya kalau kesepuluh prinsip dasar ini digunakan untuk menjelaskan dan menguraikan kajian Islam Nusantara agar mudah dikaji, dipahami, dan dioperasionalkan dalam ranah akademik dan juga dipakai untuk meluruskan kesalahpahaman sebagaimana yang dituduhkan oleh sebagian golongan terhadap ikhtiar akademik dan strategi kedaulatan kebudayaan dan peradaban ini.

Salah seorang ulama terkemuka yang bernama Muhammad bin Ali ash-Shabban, yang kemudian dikenal dengan julukan; Abu al-Irfan al-Mishri, penyusun Syarh 'ala Hasyiyah alAsymuni dan Hasyiyah ala Syarh al-Sad al-Tiftazani (wafat 1206 H), menyebutkan Mabadi Asyrah itu dalam kumpulan syairnya, sebagai berikut: 
Sesungguhnya prinsip dasar dalam setiap disiplin ilmu itu ada sepuluh, yaitu: (1) batasan definitif, (2) ruang lingkup kajian, (3) manfaat kajian, (4)perbandingan dan hubungan dengan ilmu lain, (5)keistimewaan, (6)perintis, (7) sebutan resmi, (8)sumber pengambilan kajian, (9) hukum mempelajari, (10) pokok-pokok masalah yang dikaji, lalu sebagian dengan sebagian lain mencukupi, Siapa yang menguasai semuanya akan meraih kemuliaan.

Kajian Islam Nusantara, sesuai data, dan dinamika diskursusnya, adalah sebagai berikut:

Pertama: Batasan Definitif(Al-Hadd) Pengertian: Islam (secara bahasa dan Istilah).

Menurut Ibnu Faris, secara bahasa Islam berasal dari kata Al-salam, yang secara umum berarti kesehatan dan keselamatan. Salamah adalah selamatnya seseorang dari penyakit dan gangguan. Allah adalah al-Salam, karena Dia tidak dapat tertimpa kekurangan dan cacat sebagaimana makhluk. Islam juga bermakna penyerahan diri (Ibnu Faris, Mujjam Maqayis al-Lughah, Vol 3, hal 90). Maksudnya, penyerahan diri yang dimanifestasikan dalam ketundukan kepada aturan Allah Ta'ala, yang telah dibawa oleh Rasulullah shallallahu alaihi wa sallam, baik berupa menjalankan perintah maupun meninggalkan larangan (lihat: al-Jurjani, al-Ta'rifat, hal 23).

Senada dengan pengertian sebelumnya, al-Raghib al-Ashfihani menegaskan, memeluk Islam artinya adalah masuk dalam keselamatan (al-Raghib al-Ashfihani, Mufradat al-Qur'an, hal 240).

Secara istilah, pengertian Islam adalah agama yang dibawa oleh Nabi Muhammad bin Abdillah. Umat Islam meyakiniagamanya sebagaisebuah kumpulan syariatyang menyempurnakan dan menutup risalah misi-misi langit (risalah samawiyah) dalam agama-agama sebelumnya. Dalam hadits riwayat Abu Hurairah disebutkan, Nabi memberikan pengertian tentang Islam secara praksis, yaitu Engkau menyembah Allah semata, tak menyekutukan-Nya dengan sesuatupun, engkau mendirikan shalat-shalat wajib, menunaikan zakat, berpuasa Ramadhan, dan berhaji ke Baitullah.â€ (HR. Ibnu Majah). (lihat: Ali al-Thanthawi, Tárif Am bi Din al-Islam, hal 10 dan Abdullah bin Muhammad bin Abi Syaibah, al-Mushannaf, Vol 7, hal 208).

Pengertian kata Islamâ dalam kajian Islam Nusantara sama sekali tidak berbeda dengan pengertian bahasa dan istilah sebagaimana diuraikan di atas. Penambahan kata Nusantara hanya tarkib idhafy dalam istilah ilmu Nahwu yang mengandung arti fii (di dalam) artinya Islam yang terinternalisasi dan termanifestasi di dalam hidup dan kehidupan umat muslim nusantara, bi(dengan/pada teritori) maksudnya adalah Islam yang berekspansi, berpenetrasi/ berdialog dan berdakwah pada dan dengan wilayah teritorial-geografis insan-insan nusantara sejak awal masuknya hingga kini dan juga menyimpan arti lii (untuk, bagi) yaitu Islam dan ajarannya untuk menyempurnakan dan berdialektika bersama adat, tradisi, budaya dan peradaban nusantara (local wisdom) yang mengandung nilai-nilai universal bagi harkat dan martabat kemanusiaan sejati.

Kedua: Ruang Lingkup Kajian (Al-Maudhuât)

Ruang lingkup kajian Islam Nusantara adalah berikhtiar meng-integrasikan, menginterkoneksikan dan meng-internalisasikan tiga peradaban Islam yang telah menyejarah 
dan membumi di nusantara. Ketiga peradaban tersebut yaitu Peradaban Teks (Hadhorahtun Nash), Peradaban Ilmu dan Budaya(Hadhoratul Ilm was Tsaqofah) dan Peradaban Setempat (local wisdom/Hadhorah Mahalliyyah/Waqi'iyyah).

Bertitik tolak dari kerangka dasar di atas kajian Islam Nusantara akan mengkonstruksi pendidikan Islam yang non-dikotomis, non-dualistik dan berkarakter yang utuh. Dengan demikian sebagai langkah awal kajian ini menggali dan membangun teori ilmu-ilmu keislaman yang berwatak sosial-nusantara seperti kajian kepesantrenan (pesantren studies), geneologi keilmuan (sanad ilm), tahqiq turast ulama nusantara, talaqqi pembelajaran al-Qur'an dan lain sebagainya. Selain itu kajian Islam Nusantara bertujuan mengkonversi ekspresi-ekspresi keberislaman muslim ahlussunnah wal jamaah melalui tradisi-tradisi keagamaan seperti pembacaan Aurad/wiridan, Ratib, Ruqyah, Manaqib, Maulid Nabi SAW, Nasyid, Istighosah dan Ziarah makam para wali dan ziarah ke orang-orang sholeh (disingkat: ARUMANIZ) dan Marawish, Hadrah, Barzanji dan Nasyidahan (disingkat: MARHABAN).

Ketiga: Manfaat Kajian (Al-Tsamrah)

Kajian Islam Nusantara sebagai pengembangan model dakwah yang berbasis kearifan lokal diharapkan dapat membangun paradigma keilmuan berbasis sosio-episteme kenusantaraan, dan sebagai pijakan atas ketahanan serta kedaulatan budaya dan peradaban bangsa Indonesia dalam menghadapi benturan antar peradaban (class of civilization) dengan ideologi-ideologi berbahaya yang berbasis pada ekstrimisme, materialisme, liberalisme, hedonisme, sekularisme dan lainnya. Sekaligus mencoba menawarkan bahwa budaya dan peradaban Islam Nusantara bisa sebagai alternatif pembangun kebudayaan dan peradaban dunia yang lebih berperikemanusiaan melawan hegemoni kebudayaan dan peradaban westernisme dan kofusianisme.

Keempat: Perbandingan Dan Hubungannya Dengan Ilmu/Istilah Lain (Al-Nisbah)

Kemunculan istilah Islam Nusantara dengan pengertian dan karakteristiknya tersebut di atas, tidak menafikan metode dakwah lain, selagi tidak bertentangan dengan prinsip-prinsip Ahlussunnah Wal-Jama'ah yang tawassuth, tawazun, itidal, dan tasamuh. Demikian pula, istilah Islam Nusantara tidak menafikan keberadaan Islam di negara atau wilayah lain. Perbedaan antara Islam Nusantara sebagai metodologi dakwah dengan metode yang dikembangkan di wilayah lain, baik di Afrika, Eropa, atau di wilayah Arab adalah ikhtilaf tanawwuâ (perbedaan yang tidak saling menafikan), bukan ikhtilaf tadhadh (perbedaan yang saling menafikan), karena tiap daerah memiliki karakteristiknya sendiri. Sebagai ikhtilaf tanawwuâ, keberadaan Islam Nusantara memperkaya khazanah dan metode dakwah keislaman sesuai dengan karakter wilayah ini, serta tidak menafikan universalitas (syumuliyah) Islam. Bahkan kehadiran Islam Nusantara memperkaya kajian akademik dan akan melahirkan spesialisasi-spesialisasi keilmuan yang berwatak nusantara terutama ilmu-ilmu sosial seperti ilmu sejarah, sosiologi, antropologi, filologi, histeriografi, pendidikan, ekonomi, politik, hukum dan ilmu sosial maupun alam lainnya.

Kelima: Keistimewaan (Al-Fadhl)

Keistimewaan kajian Islam Nusantara akan melahirkan sistem ilmu pengetahuan yang berwatak dan berkarakter sosial-nusantara dan mendorong tindakan-tindakan emansipatif demi 
tugas pencerdasan, humanisasi dan kesejahteraan sosial. Hal ini sebagai counter discourse terhadap sistem-sistem ilmu pengetahuan yang berkarakter anti sosial, hanya berputar-putar pada ranah kognisi sehingga melahirkan kejahatan intelektual, dominasi kekuasaan/superioritas keilmuan (scienticism) dan kediktatoran teknologis. Kajian-kajian keilmuan di Nusantara bahkan dunia selama ini baik ilmu sosial maupun ilmu alam memiliki kecenderungan positivisme, dogmatisme, ideologisme, metodologisme dan teknologisme yang ekstrim sehingga mengakibatkan hilangnya ciri sosial dan kemanusiaannya. Sepertinya ilmu-ilmu tersebut datang dari langit bukan berangkat dan dikonstruksi oleh manusia-manusia nusantara dan dari bumi nusantara yang dipijaknya. Pada umumnya ilmu-ilmu tersebut adalah produk impor dan ditemukan oleh ilmuwan-ilmuwan asing bukan original karya insan nusantara. Selain itu Islam Nusantara sebagai metodologi dakwah berguna juga untuk memetakan obyek dan strategi dakwah yang sesuai dengan karakter masyarakat di Nusantara, baik itu melalui kontekstualisasi, pribumisasi atau pun apa istilahnya terhadap manusia-manusia yang berada di bumi nusantara.

\section{Keenam: Perintis (Al-Wadhiâ)}

Perintis istilah Islam Nusantara adalah organisasi massa Islam terbesar di Indonesia, yaitu Nahdlatul Ulama (NU) melalui para akademisi Pascasarjana STAINU/UNU Jakarta. Meski tentu bukan istilah baru, namun Islam Nusantara secara khusus dikampanyekan oleh organisasi ini dan secara resmi menjadi tema besar Muktamar Ke-33 NU pada 1-5 Agustus 2015, di Jombang, Jawa Timur.

\section{Ketujuh: Sebutan Resmi (Al-Ism)}

Islam Nusantara.

\section{Kedelapan: Sumber Pengambilan Kajian (Al-Istimdad)}

Manusia-manusia nusantara adalah aktor dan sekaligus kreator disiplin kajian Islam Nusantara. Kajian tersebut berangkat dari kepekaan batin, kepedulian sosial dan ketajaman intelektual muslim nusantara akan melahirkan ilmu pengetahuan, budaya dan peradaban yang berbasis dari sosial-nusantara. Namun secara normatif kajian ini tetap bersumber pada AlQur'an, Hadits, dan ijtihad ulama Ahlussunnah Wal-Jama'ah, baik berupa produk hukum dan fatwa dari nalar muslim nusantara berupa hasil bahtsul masail, tarjih, majlis hisbah dan lainnya. Disamping itu fenomena sosial dan gejala-gejala alam di bumi nusantara juga merupakan sumber empirik kajian ini. Budaya dan peradaban yang termanifestasi di dalam seni, tradisi dan adat istiadat manusia-manusia nusantara merupakan terpenting yang bisa dinegasikan dalam diskursus ini.

\section{Kesembilan: Hukum Mempelajarinya (Al-Hukm Al-Syari)}

Jikalau kajian Islam Nusantara merupakan metodologi dan perspektif baru bagi seorang muslim nusantara maka hukumnya adalah wajib dipelajari bagi para juru dakwah yang berketetapan hati bahwa Islam Nusantara merupakan suatu cara yang bertujuan untuk menegakkan ajaran Allah SWT di muka bumi ini (li 'alai kalimatillah hiya al-ulya), serta suatu cara yang bertujuan untuk menghindari fitnah dan bahaya (mafsadah) lebih besar dalam proses dakwah dan amar maâruf nahyi munkar di wilayah Nusantara. 


\section{Kesepuluh: Pokok-pokok Masalah yang Dikaji (Al-Masail)}

Pokok pokok yang dikaji dalam Islam Nusantara antara lain; kajian tentang tradisi dan karakteristik masyarakat Nusantara, genelogi keilmuan, sanad ilmu, sanad spiritual, bahsul masail, tarjih, hisbah, pranata sosial Islam Indonesia, sejarah sosial dan intelektual muslim nusantara, filologi, sosiologi, antropologi, sejarah, historiografi, metode tahqiq, matan, syarah, hamisy, studi pesantren, metodologi pembelajaran, ekonomi, hukum, politik dan lain sebagainya.

\section{Korelasi Islam Nusantara dan Nahdlatul Ulama}

Islam Nusantara tidak bisa dipisahkan dari Nahdlatul Ulama karena NU lah yang melahirkan Islam Nusantara. Hubungan Islam Nusantara dan Nahdlatul Ulama (NU) sangat dekat bagai hubungan anak dan ibu kandung yang melhirkannnya.

Dari kronologi lahirnya Islam Nusantara jelas kita ketahui kalau Islam Nusantara merupakan istilah baru yang dicetuskan oleh Nahdlatul Ulama(NU) sebagai jawaban dan solusi situasi dan kondisi darurat tentang pemahaman Islam yang salah. Islam yang dianggap sebagai teroris yang identik dengan radikalisme, ekstrimisme dan berbagai persepsi negatif tentang Islam. Bahkan bukan hanya persepsi dan wacana melainkan telah menjadi 'identitas ' yang menyebar ke seluruh dunia sehingga sampai menimbulkan Islamic phobia di berbagai belahan dunia. Sungguh ironis dengan Islam yang sesungguhnya, Islam yang ramah, santun, damai, moderat, sumber keselamatan dunia akhirat, Islam yang menjadi rahmatan lil'alamin.

Di tengah kegaduhan dunia kepada Islam dan kondisi umat Muslim yang makin goyah pada kebenaran dan keyakinan agamanya sendiri Nahdlatul Ulama telah menjadi organisasi terdepan yang menemukan dan melahirkan perdamaian dan pemaknaan Islam pada pemahaman yang pas dan sesuai dengan istilah yang sederhana namun mudah dipahami dan dimengerti oleh umat manusia dari latar belakang agama apapun, istilah sederhana tetapi dalam maknanya; Islam Nusantara.

Bagaimana Nahdlatul Ulama bisa berperan aktif dalam setiap kondisi dan dalam berbagai situasi dengan tepat dan halus tanpa menimbulkan gesekan ditingkat umat dan bangsa tetapi justru menjadi tokoh utama dalam menjaga agama dan Bangsa ini? Mari kita lihat peran aktif Nahdlatul Ulama sebagai organisasi sosial keagamaan di masyarakat yang menjaga agama dan Bangsa Indonesia serta dunia.

\section{a. Peran Nahdlatul Ulama dalam Kehidupan Berbangsa}

Islam masuk ke Indonesia pada awal abad ke-7 hijriyah, setelah runtuhnya dinasti Abasiyyah. Fase perkembangan Nahdlatul Ulama bermula dari generasi tabi'in pasca Nabi Muhammad SAW, yaitu Imam Abu Hasan al-Asy'ari dan Imam Abu Mansur al-Maturidi hingga Imam Abu Hamid al-Ghazali.

Pada fase berikutnya seorang Ulama dari Sambas Kalimantan Barat yang bernama Syeih Ahmad Khatib Sambas (1803-1875 M) yang lama bermukim di Mekkah al-Mukarromah untuk mendalami Islam karena iklim politik di Nusantara yang tidak kondusif. Beliau pulang memabawa ajaran tarekat Qadiriyah wa naqsyabandiyah. Tarekat Qadiriyah yang diajarkan oleh 
Syeih Muhyidin Abu Muhammad Abdul Qadir bin Abi Shalih Zangi Dost al-Jailani wafat pada $1166 \mathrm{M}$ yang mengacu pada madzab Iraqi yang dibangun oleh al-Junaidi. Sedangkan Tarekat Naqsyabandiyah dibangunoleh Syeih Muhammad ibnu Muhammad Baha'udin al-Uwais al-Bukhari al-Naqsyabandiyah yang wafat pada tahun $1389 \mathrm{M}$ yang berdasar pada tradisi alKhurasani yang dipelopori oleh al-Bustami. Dua tarekat ini di ramu oleh Syeih Ahmad Khatib Sambas dalam kitab yang berjudul Fath al-Arifin.

Setelah itu diteruskan oleh Imam Nawawi al-Bantani (1813-1897) seorang Ulama yang berderajat "Mujtahid Madzab" Lalu diteruskan oleh seorang Ulama ahli hadis, Syeih Mahfudz Termas wafat pada tahun 1919. Selain itu tradisi Aswaja juga diteruskan oleh Syeih Khalil Bangkalan ( 1819-1925) beliau merupakan Ulama ahli gramatika bahasa Arab yang merupakan guru dari KH Hasyim Asy'ari. Ulama selanjutnya adalah Syeih Ihsan Muhammad Dahlan (1901-1952) Ulama ahli Tasawuf dari Kediri pengarang kitab Sirajut Thalibin sebuah kitab komentar kitab Minhajul Abidin karya Imam Ghazali.'

Dengan demikian ajaran Ablusunnah wal jamaah (Aswaja) adalah ajaran yang bersal dari Rosululloh SAW yang benar-benar memiliki silsilah yang bersambung dan mutawatir yang diikuti dan diamalkan serta diajarkan oleh para Ulama di Nusantara sampai ke KH Hasyim 'Asy'ari yang menjadi tokoh awal berdirinya Nahdlatul Ulama. Ajaran Ahlusunnah wal jamaah (Aswaja) yang pada akhirnya menjadi awal berdirinya dan mewarnai Nahdlatul Ulama.

Nahdlatul Ulama berdiri pada tanggal 31 Januari 1926. Sejak awal berdirinya Nahdlatul Ulama (NU) sebagai organisasi sosial keagamaan di indonesia telah mengalami banyak perkembangan dan peristiwa kenegaraan yang secara langsung maupun tidak sekaligus juga mempengaruhi kebijkan dan sikap para Pengurus Nahdlatul Ulama ( NU) yang mencerminkan kondisi dan kebijakan organisasi.

Kehadiran Nahdlatul Ulama memiliki peran yang sangat penting dalam kehidupan beragama, berbangsa dan bernegara. Sejak berdirinya pada tanggal 31 januari 1926, Nahdlatul Ulama tidak hanya bergerak di bidang dakwah dan pendidikan pesantren tetapi Nahdlatul Ulama juga berperan dalam kehidupan sosial kemasyarakatan.

Disamping itu Nahdlatul Ulama juga berperan dalam menjaga kondisi sosial politik di Indonesia jauh sebelum masa penjajahan. Misalnya ketika masa pendudukan Jepang di Indonesia pernah mewajibkan membungkukkan badan setiap jam 07.00 pagi ke arah kota Tokyo sebagai simbol penghormatan kepada kaisar Hirohito dan ketundukan kepada dewa matahari Amaterasi Omikami. Saat itu KH Hasyim Asy'ari rela di penjara karena tidak bersedia mematuhi perintah tersebut demi menegakkan Aqidah Islam yang hanya tunduk dan patuh menyembah Alloh SWT.

Tanggal 9 april 1945 Jepang membentuk Badan Penyelidik Usaha Persiapan Kemerdekaan Indonesia dengan hanya 15 orang anggota namun sangat mewakili aspirasi politik Islam waktu itu. Dari kalangan Nahdlatul Ulama (NU) adalah KH Wahid Hasyim. Tetapi sebagian besar anggota merupakan kaum nasionalis sekuler sehingga dengan tegas menolak Islam menjadi asas

7 Ahmad Sahal, 2015, Munawir Aziz (editor), Islam Nusantara dari Ushul Figh hingga konsep Historis, PT Mizan Pustaka, Bandung, hlm.151-153 
negara. Termasuk di dalamnya ada Rajiman widiodiningrat, Mohammad Hatta dan Ir.Soekarno. Akhirnya kelompok Islam mengalah dengan diterbitkannya Piagam Jakarta pada tanggal 22 juni 1945.

Pada tanggal 17 agustus 1945 Soekarno-Hatta memproklamirkan kemerdekaan Indonesia di jalan Pegangsaan Timur no; 56 Jakarta. Sejumlah tokoh meminta fatwa pada Rais Akbar Nahdlatul Ulama (NU) waktu itu, yaitu KH Hasyim Asy'ari tentang kelayakan Soekarno sebagai calon Presiden Republik Indonesia dan akhirnya disetujui.

Kemudian pada tanggal 21-22 oktober 1945 rapat besar Ulama dan Kyai-kyai Nahdlatul Ulama (NU) dan konsulat-konsulat berhasil mengeluarkan "Resolusi jihad" untuk mempertahankan Negara Kesatuan Republik Indonesia (NKRI) dari rongrongan penjajah yang akan kembali berkuasa dan menjajah di Nusantara ini.Segenap Ulama dan santri sekitar JawaMadura bersatu padu merapatkan barisan melawan penjajah dengan begitu dahsyat dan berhasil.

Setelah berperan aktif dalam pendirian dan pertahanan Negara Kesatuan Republik Indonesia (NKRI), pada tanggal 29 maret 1946 Nahdlatul Ulama (NU) berhasil melahirkan pendamping perjuangan organisasi yang diberi nama Muslimat Nahdlatul Ulama (NU). Kaum perempuan dari Nahdlatul Ulama (NU) diharapkan dapat turut aktif dalam membangun bangsa, seiring sejalan dengan bersama Nahdlatul Ulama (NU) dalam mewujudkan cita-cita kemerdekaan sampai sekarang.

Pada masa Orde Baru Nahdlatul Ulama (NU) mengalami tekanan di bidang pendidikan, di mana inovasi dan terobosan yang dilakukan memicu kecurigaan pemerintah akan besarnya Nahdlatul Ulama (NU) yang bisa memicu kekuasaan sosial politik melebihi pemerintah pada waktu itu. Sehingga pada waktu itu para Kyai mencetuskan ide kreatif untuk mengganti istilah Nahdlatul Ulama (NU) di lembaga-lembaga pendidikan organisasi menjadi istilah Nusantara. Sebagai contoh pada masa itu lahir Universitas Nusantara di Bandung untuk mengantisipasi kecurigaan pemerintah Orde Baru pada Perguruan Tinggi Nahdlatul Ulama (NU). ${ }^{8}$

Nahdlatul Ulama sebagai organisasi yang lahir dari kandungan Agama Islam tanpa ragu sedikitpun menerima negara kesatuan Republik Indonesia (NKRI) yang berdasarkan Pancasila dan Undang-Undang Dasar (UUD) 1945 serta semboyan kesatuan Bhineka Tunggal Ika. KH Achmad siddiq bahkan pernah menyatakan Pancasila merupakan bentuk final perjuangan Islam di Indonesia.

Bahkan sebelum kemerdekaan Indonesia telah terjadi perdebatan dikalangan Kristen yang keberatan dengan kata Ketuhanan Yang Maha Esa dengan kewajiban menjalankan syariat Islam bagi pemeluk-pemeluknya dalam Piagam Jakarta. Yang kemudian tanpa ragu menghapus tujuh kata (dengan kewajiban menjalankan syariat Islam bagi pemeluk-pemeluknya). Dengan demikian sudah 30 tahun Nahdlatul Ulama (NU) menerima Pancasila sebagai dasar Negara. Bukan hanya itu, ketika berlangsung sidang konstituante pada tahun 1956-1959 partai-partai Islam (NU, PSII, PERTI, dll) berjuang kembali untuk menjadikan Islam sebagai dasar negara, yang akhirnya Ir.Soekarno selaku Presiden mengeluarkan dekrit presiden 5 juli 1959.

8 AULA, 2015, PT AULA Media Nahdlatul Ulama, Surabaya, Agustus, hlm.10 
Sejak saat itu Pengurus Besar Nahdlatul Ulama (PBNU) di bawah komando KH Achmad Sidiq membentuk Tim yang khusus mengkaji dan mendalami kajian tentang "apakah benar Pancasila bertentangan dengan ajaran Islam.” Kemudian untuk membahas hasil kajian tim tersebut maka pada bulan desember 1983 diselenggarakan Munas Ulama Nahdlatul Ulama (NU) di Asem bagus, yang selanjutnya pada tahun 1984 diselenggarakan Muktamar Nahdlatul Ulama (NU) yang ke -27 di Asem bagus karena meskipun hasil Munas Nahdlatul Ulama (NU) di Asem bagus telah menyetujui hasil kajian tim tetapi masih perlu keputusan muktamar.

\section{b. Tipologi Kepemimpinan dalam Nahdlatul Ulama (NU)}

Ada empat tipologi kepemimpinan yang dikenal oleh Islam , khususnya oleh Nahdaltul Ulama. Pertama, tipe kepemimpinan imamah. Sebagaimana diambil dari wacana tentang imam dalam shalat. Kepemimpinan ini bercorak sufisme dan spitualisme dengan tingkat ketundukan yang bisa dikatakan mutlak. Ketundukan total pada ucapan, tingkah laku dan perintah pimpinan sebagaimana mámum / jamaah tunduk pada Imam dalam sholat. Sama sekali tidak ada sanggahan, bantahan apalagi perlawanan. Tipe kepemimpinan inilah yang digunakan oleh Syiah.

Kepemimpinan model imamah ini juga pernah dilaksanakan dalam organisasi Nahdlatul Ulama yaitu pada periode kepemimpinan Gus Dur. Segenap warga Nahdliyin mengikuti dan mengamini apa yang menjadi pilihan Gus Dur, meskipun warga NU tidak semua dan selalu memahami langkah-langkah yang diambil Gus Dur

Kedua Kepemimpinan al-qiyadah yang secara bahasa berarti kepemimpinan di Medan tempur, sehingga kepemimpinan ini berbentuk layaknya seorang jendral di medan tempur.

Model kepemimpinan ini juga pernah digunakan oleh Nahdlatul Ulama (NU), yaitu pada masa penjajahan. Pada tanggal 23 oktober 1945 Nahdlatul Ulama (NU) mengeluarkan resolusi jihad untuk melawan penjajah dengan fatwa mewajibkan berperang kepada seluruh umat Islam yang berada di radius 94 kilometer. Hasilnya sangat dahsyat, setelah fatwa ini dibacakan oleh Bung Tomo ratusan Kyai dan ribuan santri dari berbagai daerah menuju Surabaya untuk berperang melawan penjajah.

Ketiga, tipe kepemimpinan ar'ri'asah dari kata berbahasa Arab ra'sun yang berarti kepala. Bentuk kepemimpinan ini hampir sama dengan Presiden. Beberapa negara Muslim telah menggunakan bentuk republik, misalnya Mesir yang menyebut pemimpinnya Räis (kepala).

Nahdlatul Ulama (NU) pernah melaksanakan kepemimpinan jenis ini selama dua periode, yaitu saat di pimpin oleh KH Hasyim Muzadi. Bahkan ketika itu Nahdlatul Ulama (NU) benar-benar sempat berambisi mewujudkan model kepemimpinan yang sesungguhnya dengan mencalonkan KH Hasyim Muzadi sebagai wakil Presiden di Indonesia.

Keempat, model kepemimpinan ar-riayah yang secara bahasa bisa berarti perhatian, pemberdayaan dan tuntunan. Perluasan maknanya menjadi kata rakyat, karena orang yang dipimpin pasti membutuhkan perhatian, pemberdayaan dan tuntunan, maka orang yang dipimpin atau masyarakat disebut juga rakyat dan orang yang meminpin disebut Räin karena seorang pemimpin harus senatiasa memperhatikan, memberdayakan dan meuntun orang-orang yang dipimpinnya. 
Dalam kaidah fiqih disebut sebagai tasharrafu al-imam 'ala ar-raiyah man'utun bilmaslahah (kebijakan pemimpin harus atas dasar kemaslahatan rakyat). Hal ini juga sangat dekat dengan sunnah Rosul berdasarkan hadis Nabi Muhammad SAW ; kullukum ra'in wa kullukum masulun 'an räiyatibi (setiap oarang adalah pemimpin dan akan diminta pertanggung jawaban atas segala hal yang menjadi tanggungjawabnya).

Dari keempat model kepemimpinan tersebut, kepemimpinan yang tepat adalah tipe kepemimpinan yang keempat yaitu pemimpin sebagai räin yang mentinya diwujudkan oleh Nahdlatul Ulama (NU) saat ini dan di masa mendatang sehingga Nahdlatul Ulama (NU) tetap konsisten pada tujuan suci, menuju masyarakat yang sejahtera lahir batin karena pemimpinnya yang benar-benar penuh tanggung jawab dan mewujudkan cita-cita serta program organisasi secara murni tanpa tendensi dan kepentingan yang menyimpang dari tujuan.

\section{c. Idiologi dan Metodologi berpikir dalam organisasi Nahdlatul Ulama (NU)}

Sebagaimana tertulis dalam Qanun Asasi (Anggaran Dasar) yang ditulis oleh KH Hasyim Asy'ari dalam menjalani hidup warga nahdliyin berpegang pada tauhid yang diajarkan oleh Imam Abu Hasan al-'Asy'ari dan Imam Abu Mansur al-Maturidi. Sedangkan dalam ibadah dan bermasyarakat berpegang pada empat Madzab masyhur, yaitu: Maliki, Hambali, Hanafi dan Syafi'i.

Nahdlatul Ulama (NU) juga memiliki metodologi berpikir (manhaj alfikrah al-nahdliyah) yang sudah mendarah daging dengan Pengurus Nahdlatul Ulama (NU) dan warga nadhliyin, yaitu; tawasuth atau moderat, tawazun atau seimbang, tasammuh atau toleran dan itidal atau adil.

Metodologi inilah yang menjadi pondasi dasar berpikir dan bergeraknya Nahdlatul Ulama (NU). Setiap pemikiran, kebijakan dan tindakan para Pengurus Nahdlatul Ulama (NU) dari tingkat Nasional / pusat hingga ranting atau desa.

Setiap pemikiran dan gerak langkah para Pengurus Nahdlatul Ulama (NU) harus mengacu pada idiologi dan dasar pemikiran organisasi tidak bisa menerapkan pemikiran dan tindakan yang bertentangan atau seenaknya, yang bersal dari pendapat pribadi tanpa dasar alur idiologi dan pemikiran di tubuh organisasi Nahdlatul Ulama (NU). Secara garis besar ditegaskan oleh KH Said Aqil Siraj, da lam perkara aqidah mengikuti salah satu dari aliran Abu Hasan alAsy'ari atau Abu Mansyur al-maturidi, dalam 'ubudiyah mengikuti salah satu madzab 4 ; Imam Abu Hanifah, Imam Maliki, Imam Hambali atau Imam Syafi'i, dalam tasawuf mengikuti salah satu sari Imam besar ahli tasawuf; Abu Qasim al-Junaidi al-Baghdadi (wafat $297 \mathrm{H}$ ) atau Abu Hamid al-Ghazali (wafat $505 \mathrm{H}$ ). ${ }^{?}$

Namun demikian pemikiran, kebijakan dan gerak langkah dalam organisasi Nahdlatul Ulama (NU) tidak terlepas dari pengaruh pemikiran, dan gerak langkah Pengurus Besar Nahdlatul Ulama (PBNU). Termasuk metode berpikir yang digunakan dalam kepengurusan.

Pemikiran dalam organisasi Nahdlatul Ulama (NU) berakar dari Nabi Muhammad SAW yang diambil dari teladan para Khulafaurrosyidin ,hasil dari analog dan analisa serta ijtihaj

9 Ahmad Sahal, 2015, Munawir Aziz (editor), Islam Nusantara dari Ushul Fiqh hingga konsep Historis, PT Mizan Pustaka, Bandung, hlm.138-139 
para Ulama Nahdliyah. Pemikiran yang mengacu pada kaidah ushul fiqh dan fiqh. Jadi bukan pemikiran yang bertentangan apalagi melanggar ajaran Islam atau lepas dari Islam murni. Justru Nahdlatul Ulama (NU) adalah organisasi yang sangat taat pada ajaran Islam yang asli, yang berdasar al-Qur'an dan al-Hadis sehingga tidak mau terlepas dari manhaj / metodologi berpikir dalam Islam yang bersumber dari Allah SWT dan Rosululloh Muhammad SAW.

Dalam pelaksanaannya Nahdlatul Ulama (NU) tidak saklik hanya berdasarkan teks-teks al-Qur'an dan al-Hadist, melainkan bersifat fleksible, luwes menyesuaikan kondisi sosial, politik dan keadaan masyarakat setempat atau secara kontekstual. Hal ini mengacu pada pemikiran Khalifah Umar bin Khattab r.a yang sering menggunakan metode berpikir maslahah mursalah (kemaslahatan masyarakat).

Misalnya Metode berpikir yang sangat masyhur, dekat, lekat dan mengakar kuat di tubuh Nahdlatul Ulama (NU) adalah metode berpikir yang dikenalkan dan dibiasakan oleh Ulama besar Nahdlatul Ulama (NU), KH Sahal Mahfudz seorang Ulama ahli fiqh yang sangat kharismatik, 'alim dan tawadu' pemerhati dan penyebar kemaslahat umat yang selanjutnya pemikiran beliau dikenal dengan istilah fiqh sosial.

Secara epistimologis dibangun diatas lima metodologi, kontekstualisasi doktrin fiqh ; beralih dari madzhab qouli (tekstual) menuju manhaji (metodologis), verifikasi doktrin ashal (fundamentalis-permanen) yang tidak bisa berubah dan far'u (instrumental) yang bisa berubah, menghadirkan fiqh sebagai etika sosial dan mengenalkan pemikiran filosofis terutama pada masalah sosial budaya.

KH Sahal Mahfudz menuangkan dalam beberapa hal, misalnya; pendayagunaan zakat, konservasi ekologis, emansipasi perempuan, pendidikan integralistik, pluralisme, dan pengentasan kemiskinan dengan tetap berpijak pada kekayaan tradisi pesantren melalui pendekatan sosial humaniora yang transformatif.

Pemikiran KH Sahal Mahfudz ini adalah upaya kritis beliau atas fiqih konvensial yang sulit diterapkan dijadikan dasar tranformasi sosial, budaya, dan ekonomi masyarakat. Tetapi upaya kritis KH Sahal Mahfudz ini adalah kritisme moderat yang tetap mengedepankan kemaslahatan umat, bukan kritis yang kebablasen seperti yang dilontarkan oleh Sadiq jalal al-Azm, Nashr Hamid Abu Zaid dan Ulil Abshar yang tidak diterima oleh kalangan Nahdlatul Ulama (NU). Karena KH Sahal Mahfudz sendiri berpendapat bahwa fiqh sebetulnya adalah wilayah ijtihad, maka suatu ijtihad yang tidak mendatangkan kemaslahatan umum (maslahat al-ammah) harus direvisi. Bisa dikatakan pendapat KH Sahal Mahfudz itu mengadopsi konsep maslahat Abu Ishaq as-Syatibi (W.1388) dalam kitan alMuwafaqaat.

Dari berbagai metode berpikir, tipologi kepemimpinan dan idiologi yang ada dalam organisasi Nahdlatul Ulama (NU) menyebabkan korelasi yang sangat ideal bagi Nahdlatul Ulama (NU) untuk melahirkan Islam Nusantara. Islam yang diterima oleh semua umat manusia di belahan bumi manapun dengan agama apapun untuk mewujudkan perdamaian. Islam Nusantara adalah Islam moderat yang menangkal radikalisme, terorisme, extrimisme dan menerima pluralisme. 


\section{Penutup}

Dari pembahasan tentang Islam Nusantara sebagai manifestasi Nahdlatul Ulama dalam mewujudkan perdamaian, dapat kita tarik kesimpulan bahwa:

Islam Nusantara adalah istilah baru yang muncul sebagai solusi untuk mewujudkan perdamaian di muka bumi yang sedang mengalami dekadensi pemahaman terhadap Islam yang diklaim sebagai terorisme, extrimisme dan berbagai persepsi negatif lainnnya terhadap Islam sampai munculnya Islamic phobia

Meskipun Islam merupakan istilah baru namun demikian Islam Nusantara bukan Islam baru. Islam Nusantara adalah Islam murni ajaran Nabi Muhammad SAW hanya saja di implementasikan dan diaplikasikan sesuai adat kebiasaan di Nusantara/ Indonesia tanpa merubah ajaran Islam.

Nahdlatul Ulama merupakan organisasi sosial keagamaan yang berkembang di Nusantara yang telah melahirkan dan meyebarkan Islam Nusantara di Indonesia khususnya dan di dunia umumnya untuk mewujudkan perdamaian.

Islam Nusantara adalah Islam yang mengedepankan rahmat/kasih sayang, yang menyejukkan, melindungi, moderat, menerima budaya lokal yang tidak bertentangan dengan ajaran Islam, yang mementingkan dialog atau menyelaraskan nash syar'i dan realitas, bukan hanya ritual, melainkan tetap sesuai dengan basis pengetahuan dan khazanah budaya sehingga terwujudnya harmoni antara agama, budaya dan bangsa itu sendiri yang merupakan manifestasi ajaran Ahlusunnah wal jamaah ( Aswaja) yang diajarkan dan diamalkan oleh Nahdlatul Ulama (NU) baik berasal dari dalam organisasi Nahdlatul Ulama (NU) itu sendiri maupun dari organisasi lain yang sepaham dengan Nahdlatul Ulama (NU). Karena di luar Nahdlatul Ulama (NU) banyak yang mengklaim sebagai Islam Ahlusunnah wal jamaah tetapi dalam pengamalan ajarannya tidak sama dengan NU, padahal Islam Nusantara adalah pemahaman Islam gagasan NU.

\section{BIBLIOGRAFI}

Abdullah Ubaid \& Mohammad Bakir, Nasionalisme dan Islam Nusantara, Jakarta: Kompas Media Nusantara, 2015.

Sahal, Akhmad, Aziz, Munawir, Islam Nusantara dari Ushul Fiqh hingga Konsep Historis, Bandung: Mizan Pustaka, 2015. Aula, Aula Media Nadhlatul Ulama Surabaya: 2015.

Suminto, Aqib, Problematika Dakwah, Jakarta: Pustaka Panjimas, 1984. 
Aceh, Abu Bakar, Beberapa Catatan Mengenai Dakwah Islam, Semarang: Ramadhani, 1971.

Syukir, Asmun, Dasar-dasar Strategi Dakwah Islam, Surabaya: Al-Ikhlas, 1983.

Saleh, Abdul Rosya, Manajemen Dakwah Islam, Jakarta: Bulan Bintang, 1977.

Zaedan, Abdul Karim, Ushulud Dakwah, terj.H.M Asnawi Syukur, Dasar-dasar Ilmu Dakwah, Jakarta: Media Dakwah, 1983.

Arifin, H.M., Pedoman Pelaksanaan Bimbingan dan Penyuluhan Agama.Jakarta: PT Golden Terayon Press, 1994.

Umawi, Barmawi, Azas-azas Ilmu Dakwah, Semarang: Ramadhani, 1987.

Muhajir, Noeng, Metode Penelitian Kualitatif, Rake Sarasin, 2001.

Singarimbun, Masri, Metode Penetian Survey, Jakarta: LP3S.

Moleong, Lexy, Metode Penelitian Kualitatif, Bandung: Remaja Rosda Karya, 2001.

Raharjo, M. Dawam, Masyarakat Madani: Agama, Kelas Menengah Dan Perubahan Sosial. Jakarta: LP3ES, 1999.

Romly, A.M., Penyuluhan Agama Menghadapi Tantangan Baru. Jakarta: Bina Rena Pariwara, 2001.

Arikunto, Suharsini, Metode Penelitian Suatu Pendekatan Praktek, Jakarta: Rineke Cipta 2001.

Hadi, Sutrisno, Metodologi Research I. Yogyakarta: Andi offset, 2004.

Tim penyusun Departemen Agama Direktorat Jenderal Kelembagaan Agama Islam Proyek Bimbingan dan Dakwah Agama Islam Pusat, 2003. Pedoman Monitoring dan Evaluasi Penyuluh Agama Islam. Jakarta : Depag dan Dirjen Kelembagaan Agama Islam.

Tim Penyusun Departemen Agama RI Direktorat Jenderal Bimbingan Masyarakat Islam dan Urusan Haji, Panduan Penyuluh Agama. Jakarta: Depag dan Dirjen Bimbingan Masyarakat Isalam dan Urusan Haji, 1987.

Tim Penyusun Departemen Agama RI Direktorat Jenderal Kelembagaan Agama Islam Bagian Proyek Peningkatan Pendidikan Agama RI Pada Masyarakat dan Tenaga Keagamaan, Panduan Tugas Operasional Penyuluh Agama islam Utama. Jakarta: Depag dan Dirjen Kelembagaan Agama Islam, 1987.

Tim penyusun Kanwil Depag Provinsi Jawa Tengah, Himpunan Peraturan-Peraturan Bidang Penama. Semarang: Kanwil Kemenag Provivinsi Jawa Tengah, 2010.

Tim Penyusun Naskah Buku Direktori Lembaga Dakwah, Direktori Lembaga Dakwah. Jakarta: Lembaga Dakwah, 1993. 